\title{
Deteksi Gen Litik BRLF1 Epstein-Barr Virus pada Penderita Karsinoma Nasofaring
}

\author{
Tri Yulia Ningsih ${ }^{1}$, Daniel Joko Wahyono ${ }^{1}$, Nur Signa Aini Gumilas ${ }^{2}$ \\ ${ }^{1}$ Fakultas Biologi Universitas Jenderal Soedirman, Purwokerto \\ ${ }^{2}$ Fakultas Kedokteran Universitas Jenderal Soedirman, Purwokerto \\ Email: tri.yulia.ningsih34@gmail.com
}

\begin{abstract}
Nasopharyngeal carcinoma (NPC) is a malignant tumor that grows in the nasopharynx with a predilection for the Rosenmuller fossa. Epithelial malignancy is often found in Chinese populations and Southeast Asia including Indonesia. Undifferentiated nasopharyngeal carcinoma (NPC WHO-3) type is 100\% associated with Epstein-Barr virus (EBV) infection. Bam-HI R Leftward Reading Frame 1 (BRLF1) lytic gene has an important function as a transition mediator of latent phase to the lytic phase in EBV cycle. Detection of BRLF1 gene by PCR can be used for NPC diagnosis. The aim of this study is to identify BRLF1 lytic genes as molecular markers of Epstein-Barr virus in nasopharyngeal carcinoma patients with conventional PCR method and to determine the sensitivity of conventional PCR method to detect BRLF1 gene. The research design was cross sectional study. A total of 22 DNA samples were isolated from venous blood of NPC patients from RSUD Prof dr Margono Soekarjo, Purwokerto with informed consent. BRLF1 gene identification is done with conventional PCR technique. The results of this research showed that BRLF1 genes as molecular markers lytic cycle of Epstein-Barr virus in nasopharyngeal carcinoma patients can be identified conventional PCR technique that will produced DNA $157 \mathrm{bp}$. BRLF1 gene was detected in 16 samples $(72.73 \%)$ of 22 samples of this study.
\end{abstract}

Key words: Bam-HI R Leftward Reading Frame 1 gene, Epstein-Barr Virus, Nasopharyngeal cancer

\begin{abstract}
Abstrak
Karsinoma nasofaring (KNF) adalah tumor ganas yang tumbuh pada daerah nasofaring dengan predileksi di fosa Rosenmulleri. Keganasan epitel ini sering ditemukan pada populasi Cina dan Asia Tenggara termasuk Indonesia. Tipe Karsinoma nasofaring yang tidak berdiferensiasi (KNF WHO-3) 100\% berhubungan dengan infeksi Epstein-Barr virus (EBV) . Gen litik Bam-HI R Leftward Reading Frame 1 (BRLF1) memiliki fungsi penting sebagai mediator transisi fase laten menuju fase litik siklus EBV. Deteksi gen BRLF1 dengan PCR dapat digunakan untuk mendiagnosis KNF. Tujuan dari penelitian ini adalah untuk mengidentifikasi gen litik BRLF1 sebagai penanda molekuler virus Epstein-Barr pada pasien karsinoma nasofaring dengan metode PCR konvensional dan menentukan sensitivitas metode PCR konvensional untuk mendeteksi gen BRLF1. Desain penelitian yang digunakan adalah cross sectional study. Sejumlah 22 sampel DNA diisolasi dari darah vena pasien NPC dari RSUD Prof dr Margono Soekarjo, Purwokerto dengan informed consent. Identifikasi gen BRLF1 dilakukan dengan metode PCR konvensional. Hasil penelitian ini menunjukkan bahwa gen BRLF1 sebagai penanda molekuler siklus litik virus Epstein-Barr pada pasien karsinoma nasofaring dapat diidentifikasi dengan PCR konvensional yang akan menghasilkan DNA 157 bp. Gen BRLF1 terdeteksi pada 16 sampel (72,73\%) dari 22 sampel penelitian ini.
\end{abstract}

Kata Kunci : Gen litik Bam-HI R Leftward Reading Frame 1, virus Epstein-Barr.

\section{Pendahuluan}

Karsinoma nasofaring (KNF) merupakan tumor ganas pada sel epitel nasofaring. Insidensi KNF pada tahun 2008 diperkirakan sekitar 84.400 kasus dan 51.600 kasus diantaranya menyebabkan kematian (Jemal et al., 2011). Mayoritas penderita KNF saat didiagnosis sudah berada pada stadium lanjut karena tidak memiliki gejala spesifik dan sulitnya pemeriksaan rongga nasofaring (Savitri \& Sofia, 2012).

KNF mempunyai perbedaan signifikan dalam distribusi geografis dan etnis. Ras Mongoloid merupakan faktor genetik yang dominan sebagai etiologi KNF, sehingga kekerapannya cukup tinggi pada penduduk di wilayah Cina, Vietnam, Thailand, Malaysia,
Singapura, dan Indonesia (Cottrill \& Nutting, 2003). Insidensi KNF di Indonesia menduduki urutan ke-5 dari semua insidensi kanker (Soepardi et al., 2007). Setiap tahunnya ditemukan 120 kasus baru di RSUD Prof. dr. Margono Soekarjo (RSMS), Purwokerto (Savitri \& Sofia, 2012).

Etiologi KNF bersifat multifaktor yang terdiri dari faktor genetik, infeksi Epstein Barr virus (EBV), dan faktor lingkungan.Faktor genetik penyebab KNF yaitu kelainan kromosom, polimorfisme gen, dan jenis ras. Faktor lingkungan penyebab KNF yaitu kebiasaan makan ikan asin dan makanan awetan yang mengandung nitrosamine, pajanan asap kayu, zat karsinogen, gas kimia, asap industri, asap obat nyamuk, dan asap rokok (Roezin, 1999). 
KNF tipe karsinoma tidak berdiferensiasi (undifferentiated carcinoma) atau KNF WHO-3 telah terbukti konsisten dengan infeksi EBV (Steven et al., 2006). EBV mempunyai dua fase dalam daur infeksinyae yaitu fase litik dan fase laten. Pada fase litik EBV terjadi serangkaian ekspresi gen litik, replikasi genom virus, dan produksi virion. Infeksi litik EBV dibagi menjadi tiga fase, yaitu fase immediate-early, fase early, dan fase late(Chang et al., 2004). Gen litik immediate-early EBV yaitu BRLF1 berperan penting sebagai mediator transisi dari fase laten menjadi fase litik dalam daur infeksi EBV. Deteksi gen litik BRLF1EBV dapat digunakan untuk menegakkan diagnosisKNF yang lebih dini dan meningkatkan efisiensi dalam penanganan KNF (Cacais, 2008).

Berdasarkan latar belakang yang telah disampaikan, maka permasalahan yang perlu dikaji adalah apakah pada penderita KNF dapat diidentifikasi gen BRLF1 dengan teknik PCR (Polymerase Chain Reaction) konvensional dan bagaimanakah sensitivitas metode PCR konvensional dalam mendeteksi gen BRLF1. Penelitian ini bertujuan untuk melakukan identifikasi gen BRLF1 sebagai petanda molekuler siklus litik Epstein-Barr virus pada penderita karsinoma nasofaring dengan teknik PCR konvensional dan mengetahui sensitivitas metode PCR konvensional dalam mendeteksi gen BRLF1. Hasil penelitian ini diharapkan dapat memberikan informasi ilmiah tentang teknik molekuler untuk identifikasi gen-gen EBV pada penderita KNF, sehingga analisis molekuler DNA EBV dapat dijadikan acuan para klinisi dalam diagnosis dan penanganan KNF.

\section{Metode}

\section{Lokasi dan Waktu Penelitian}

Penelitian ini dilaksanakan di Poli THT RSUD Prof. dr. Margono Soekarjo Purwokerto dan Laboratorium Genetika dan Biologi Molekuler Fakultas Biologi Unsoed. Penelitian ini dilakukan selama enam bulan dari bulan September 2014Februari 2015.

\section{Rancangan Penelitian}

Rancangan penelitian yang digunakan adalah metode deskriptif yang berbentuk studi belah lintang (cross sectional) yaitu pengambilan sampel dilakukan satu kali tanpa perlakuan. Sampel penelitian adalah jaringan darah vena penderita KNF dengan diagnosis pasti hasil pemeriksaan Patologi Anatomi dari Poli THT RSUD Prof. dr. Margono Soekarjo, Purwokerto. Menurut Incidency Primary Cancer in Indonesia Pathology Base (1990), proporsi jumlah pasien KNF dibandingkan dengan kanker lain adalah $5,46 \%$, maka besar sampel minimal yang diperlukan dalam penelitian ini adalah 22 orang.

\section{Variabel}

Variabel yang diamati dalam penelitian ini terdiri dari variabel bebas dan tergantung. Variabel bebas yang diamati adalah ukuran produk PCR (am plikon DNA) fragmen gen BRLF1, sedangkan variabel tergantung adalah eksistensi gen BRLF1 dari genom EBV.

\section{Cara Kerja}

\section{Pengambilan sampel}

Subyek penelitian adalah penderita KNF dengan diagnosis pasti dari hasil pemeriksaan Patologi Anatomi dan memiliki informed consent. Kriteria inklusi subyek penelitian adalah pertama, penderita KNF dengan diagnosis pasti dari hasil pemeriksaan Patologi Anatomi sebelum terapi yang berusia $>15$ tahun; kedua, sampel penelitian yang dapat ditentukan tipe KNFnya; ketiga sampel penelitian yang dapat ditegakkan stadium KNFnya.Kriteria eksklusi subyek penelitian adalah pertama, penderita KNF dengan diagnosis pasti dari hasil pemeriksaan Patologi Anatomi yang berusia <15 tahun; kedua, penderita yang didiagnosis bukan KNF; ketiga penderita KNF pasca terapi dan mengalami kekambuhan (relaps); keempat sampel penelitian yang tidak mempunyai informed consent. Sampel darah vena (tepi) sejumlah 1-3 ml diambil dari subyek penelitian dan dimasukkan kedalam tabung vaccuteiner yang menandung zat antikoagulan (EDTA).

\section{Isolasi DNA EBV}

Isolasi DNA virus dilakukan sesuai dengan protokol kit Purelink ${ }^{\circledR}$ Viral DNA Minikit (Invitrogen, USA) hingga diperoleh $100 \mu$ DNA. Tahap isolasi dilakukan pada 22 sampel darah penderita KNF. Menurut Surzycki (2000), DNA hasil isolasi yang Tahapan isolasi DNA terdiri dari tiga tahap, yaitu perusakan sel, pemisahan DNA dari bahan lain, dan pemurnian DNA.DNA hasil isolasi diuji secara kualitatif menggunakan elektroforesis dan secara kuantitatif dengan menggunakan spektrofotometer nanodrop.

\section{Amplifikasi gen BRLF1menggunakan teknik PCR}

Teknik PCR dua tahap digunakan untuk mendeteksi gen BRLF1 pada sampel penderita KNF. Primer yang digunakan pada PCR tahap I dan II mengamplifikasi sekuens DNA spesifik dari gen BRLF1 menghasilkan amplikon DNA berukuran $157 \mathrm{pb}$, primer sisi kiri (forward/leftprimer) adalah5'AGCAGAGCGAGCGGGAAGAG-3' dan primer sisi kanan (reverse/rightprimer) adalah 5'TCGCTCTCTTGGTGGACCGC-3' (Wahyono et al, 2016). Amplifikasi tahap I menggunakan campuran PCR (PCR mix) dibuat dalam volume $15 \mu \mathrm{l}$ menggunakan $7,5 \mu \mathrm{l}$ kit Thermo Scientific 
DreamTag PCR Master Mix (2X), $1 \mu$ lprimer forward10 $\mu \mathrm{M}, 1 \mu \mathrm{l}$ primer reverse10 $\mu \mathrm{M}, 3 \mu \mathrm{l}$ DNAcetakan, dan 2,5 $\mu \mathrm{l} \mathrm{ddH}_{2} \mathrm{O}$. Kit Thermo Scientific DreamTag PCR Master Mix (2X) komposisinya terdiri dari DreamTaq DNA polymerase, DreamTaq buffer, $4 \mathrm{mM} \mathrm{MgCl}_{2}, 0,4$ mM dATP, 0,4 mM dCTP, 0,4 mM dGTP, dan 0,4 mM dTTP. Pada amplifikasi tahap II, campuran PCR (PCR mix) dibuat dalam volume $15 \mu \mathrm{l}$ menggunakan 7,5 $\mu \mathrm{l}$ kit Thermo Scientific DreamTag PCR Master Mix (2X), $1 \mu$ l primer forward10 $\mu \mathrm{M}, 1 \mu \mathrm{l}$ primer reverse10 $\mu \mathrm{M}, 1 \mu \mathrm{l}$

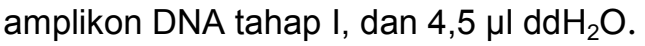

Amplifikasi dilakukan pada mesin thermocycles Primus® 25 well thermal cycler (PeqLab GmBH, Germany) dalam 2 tahap yang masing-masiing dilakukan sebanyak 35 siklus dengan kondisi PCR sebagai berikut: denaturasi awal $95^{\circ} \mathrm{C}$ selama 5 menit, denaturasi $95^{\circ} \mathrm{C}$ selama 30 detik, penempelan $63^{\circ} \mathrm{C}$ selama 30 detik, pemanjangan $72^{\circ} \mathrm{C}$ selama 30 detik, dan pemanjangan akhir $72^{\circ} \mathrm{C}$ selama 7 menit.

\section{Visualisasi hasil deteksi gen BRFL1 menggunakan elektroforesis gel agarosa}

Hasil amplifikasi DNA dipisahkan menggunakan metode elektroforesis gel agarosa $2 \%$ selama 60 menit dengan voltase $90 \mathrm{~V}$ dan kuat arus $500 \mathrm{~mA}$. Hasil elektroforesis divisualisasi dengan menggunakan Gel-Doc 1000 (Hitachi, Japan) yang dapat dilihat pada layar komputer.

\section{Interpretasi data}

Hasil identifikasi gen BRLF1 dan senstivitas metoda PCR konvensional yang didapatkan dianalisis dengan metode deskriptif dengan caramembandingkan hasildeteksi yang didapatkan dengan hasil dari penelitian-penelitian sebelumnya yang berkaitan.

\section{Hasil dan Pembahasan}

\section{Karakteristik Sampel Penelitian}

Penelitian ini menggunakan 22 sampel darah pasien KNF yang diambil di RSUD Prof. dr. Margono Soekarjo, Purwokerto. Sebanyak 21 sampel (95,56\%) adalah KNF TIPE WHO-3 dan 1 sampel $(4,44 \%)$ adalah KNF WHO-2. Menurut Ariwibowo (2013), KNF WHO-2 dan KNF WHO-3 paling banyak dijumpai di daerah endemik KNF, seperti di Tiongkok Selatan, Asia Tenggara, dan Afrika Utara. Sementara KNF WHO-1 lebih sering dijumpai di Eropa dengan prognosis yang lebih buruk.

Semua pasien KNF di RSMS yang menjadi subjek penelitian adalah suku Jawa. Hal ini disebabkan letak geografis RSMS yang berada di Purwokerto, Kabupaten Banyumas, Jawa Tengah dan banyaknya orang Jawa yang berobat ke RSMS.Meskipun etnis Tiongkok memiliki risiko KNF yang tinggi, namun tidak ditemukan adanya pasien beretnis Tiongkok yang berobat ke RSMS. Berdasarkan penelitian yang dilakukan Yurnadi et al. (2011) di RSCM Jakarta, sedikitnya pasien etnis Tiongkok yang berobat di rumah sakit pemerintah disebabkan etnis Tiongkok mempunyai tingkat sosioekonomi yang tinggi sehingga lebih memilih berobat ke rumah sakit swasta atau ke luar negeriHasil pengecekan kualitas DNA dengan menggunakan gel elektroforesis $2 \%$ dengan running selama 60 menit, voltase $90 \mathrm{~V}$, dan kuat arus $500 \mathrm{~mA}$ menunjukkan hasil yang cukup memuaskan di mana DNA yang diperoleh terlihat utuh (Gambar 1). DNA yang utuh ditandai dengan tidak adanya smear DNA yang dielektroforesis. Hal ini menjadi penting karena pada proses PCR, DNA yang masih utuh akan memberikan hasil yang relatif lebih akurat (Syafaruddin \& Tri, 2011).
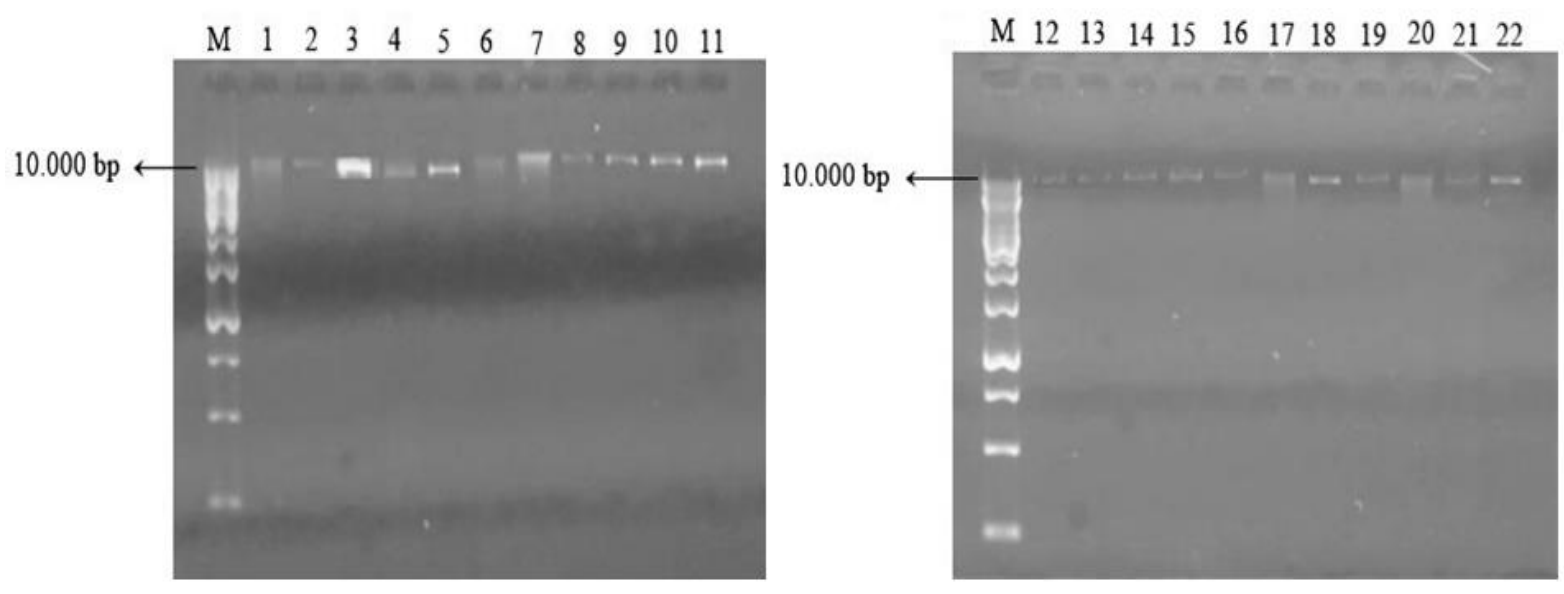

Gambar 1.Visualisasi DNA sampel KNF (M, Marka DNA 1 kb; 1-22, DNA sampel KNF) 
Kuantifikasi sampel DNA dilakukan untuk melihat konsentrasi dan kemurnian DNA.DNA hasil isolasi kemudian diuji secara kuantitatif dengan menggunakan spektrofotometer nanodrop (Tabel 1). Kuantifikasi ini dilakukan untuk melihat konsentrasi dan kemurnian DNA. Konsentrasi sampel DNA diukur nilai absorbansinya pada panjang gelombang $(\lambda) 260 \mathrm{~nm}$, sedangkan kemurnian DNA dari kontaminasi ditentukan dengan perbandingan hasil absorbansi pada $\lambda$ $260 / 280$ dan $\lambda$ 260/230. Kuantifikasi DNA hasil isolasi yang didapatkan beragam baik dari segi konsentrasi maupun kemurniannya. Rata-rata nilai konsentrasi DNA adalah $50,89 \pm 32,54 \mathrm{ng} / \mu \mathrm{L}$. Pada metode spektrofotometri digunakan pengukuran absorbsi pada panjang gelombang tertentu karena DNA (asam nukleat) mempunyai struktur cincin aromatik basa nitrogen yang dapat mengabsorbsi sinar UV. Nilai absorbansi $\lambda$ 260/280 $\mathrm{nm}$ yang didapat yaitu antara 1,3862,375 . Nilai absorbansi $\lambda 260 / 230 \mathrm{~nm}$ yaitu antara 0,136-0,960.Beberapa sampel tidak dapat dideteksi kemurniannya menggunakan spektrofotometer nanodrop. Menurut Sambrook \& Russel (1989), DNA dikatakan murni apabila mempunyai nilai perbandingan absorbansi $\lambda$ 260/280 nm berkisar 1,8-2,0. Pada kemurnian DNA yang nilainya lebih rendah dari 1,8 menunjukkan sampel DNA terkontaminasi oleh protein, sedangkan kemurnian DNA yang nilainya lebih tinggi dari 2,0 artinya sampel DNA terkontaminasi oleh RNA. Pada perbandingan absorbansi $\lambda$ 260/230 nm DNA murni berkisar antara 2-2,2. Jika nilainya lebih rendah dari 2 maka DNA terkontaminasi oleh karbohidrat, bahan organik, atau kemikalia lain.

Tabel 1. Hasil Uji Kualitatif DNA Hasil Isolasi

\begin{tabular}{cccc}
\hline \multirow{2}{*}{ No } & \multirow{2}{*}{ Konsentrasi DNA $(\mathrm{ng} / \mu \mathrm{l})$} & \multicolumn{2}{c}{ Kemurnian DNA } \\
\cline { 2 - 4 } & & A260/280 & A260/230 \\
\hline 1 & 44,5 & - & 0,960 \\
2 & 42,5 & 1,848 & 1,000 \\
3 & 106 & 1,819 & 0,214 \\
4 & 81,0 & 2,104 & 0,623 \\
5 & 12,0 & - & 0,279 \\
6 & 67,5 & - & - \\
7 & 31,5 & 1,853 & 0,232 \\
8 & 17,5 & 1,944 & 0,593 \\
9 & 21,5 & - & - \\
10 & 16,0 & 2,00 & 0,348 \\
11 & 88,0 & 1,386 & 0,127 \\
12 & 15,5 & - & 0,193 \\
13 & 34,5 & 1,769 & 0,639 \\
14 & 42,5 & - & - \\
15 & 63,5 & 2,268 & 0,136 \\
16 & 27,0 & - & - \\
17 & 42,0 & - & 0,158 \\
18 & 9,5 & 2,375 & 0,352 \\
19 & 87,0 & 1,464 & 0,179 \\
20 & 81,5 & - & 0,604 \\
21 & 68,5 & - & - \\
22 & 120 & 1,391 & 0,423 \\
\hline
\end{tabular}

\section{Hasil Deteksi Gen BRLF1 Menggunakan Teknik PCR}

Semua sampel darah pasien KNF yang diperoleh kemudian diisolasi DNAnya untuk dideteksi apakah terdapat gen litik BRLF1 menggunakan metode PCR konvensional dua tahap. Metode PCR dua tahap ini memungkinkan untuk memperoleh lebih banyak jumlah amplikon DNA yang dihasilkan karena jumlah DNA virus relatif rendah (Haryanto \& Sofia, 2012). Hasil PCR dua tahap kemudian dipisahkan dengan elektroforesis gel agarosa $2 \%$. Hasil elektroforesis kemudian divisualisasi dengan Gel-Doc 1000 (Hitachi, Japan). Pita DNA yang terbentuk dibandingkan ukurannya dengan DNA ladder 100 bp. Hasil PCR dua tahap dengan menggunakan primer yang spesifik berhasil dan bernilai positif dengan produk PCR berukuran 157 bp (Gambar 2). Hal tersebut menunjukkan bahwa gen BRLF1 telah berhasil diamplifikasi. 


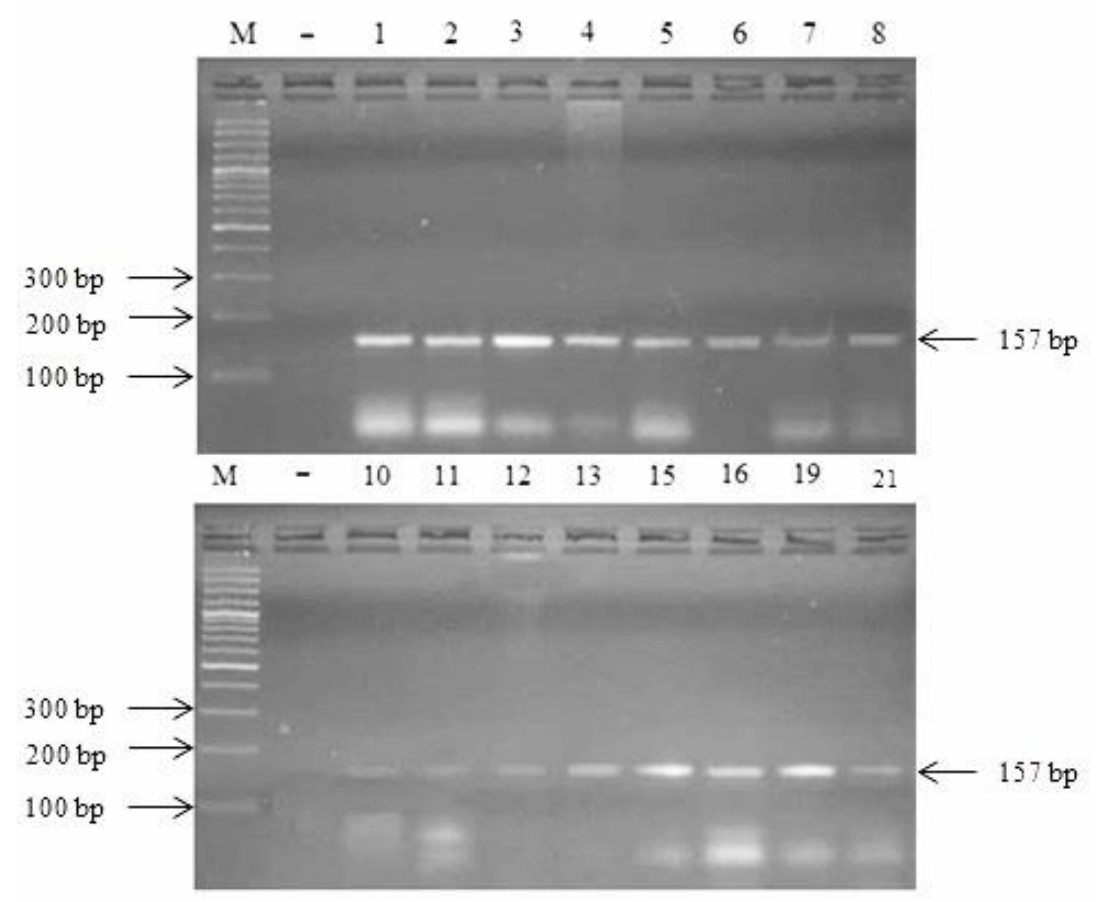

Gambar 2. Visualisasi produk PCR gen BRLF1 DNA EBV (M, Marka DNA 100 bp;-, Kontrol Negatif; 1-21,Produk PCR gen BRLF1)

Hasil penelitian menunjukkan bahwa dari 22 sampel DNA pasien KNF yang dilakukan PCR, $16(72,73 \%)$ sampel positif terdeteksi gen BRLF1 dan 6 sampel $(27,27 \%)$ tidak terdeteksi gen BRLF1. Infeksi EBV pada KNF menunjukkan tahap infeksi fase immediate-early (IE) akan mengekspresikan gen BRLF1 sebagai transaktivator replikasi virus yang berfungsi mengatur ekspresi baik gen virus seluler maupun lainnya, sehingga dapat digunakan untuk petanda biologi infeksi EBV pada KNF (Bhende et al., 2004). Gambar 3.menunjukkan grafik persentase hasil deteksi gen BRLF1 dari sampel DNA pasien KNF menggunakan metode PCR konvensional.

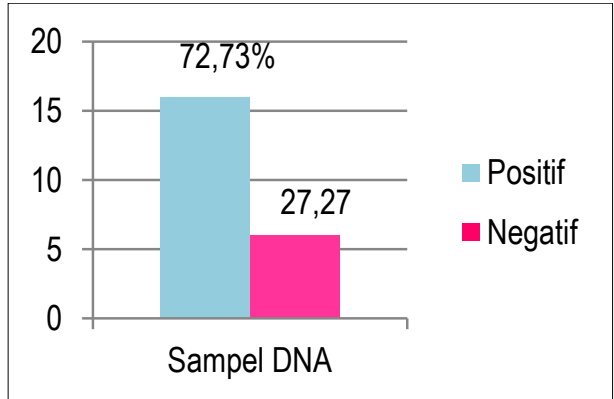

Gambar 3. Persentasi sensitivitas deteksi gen BRLF1 dengan metode PCRkonvensional

Deteksi DNA tumor yang diturunkan dalam sirkulasi pasien penyakit ganas menggunakan strategi berbasis PCR telah membuka jalan baru untuk diagnosis dan pemantuan perkembangan penyakit (Lo et al., 1999).KNF yang terkait dengan infeksi EBV sering ditemukan di Asia Tenggara, tetapi jarang ditemukan di Amerika Utara dan Eropa (Tselis \& Hal, 2006). Teknik PCR dilakukan untuk mengamplifikasi fragmen DNA dari EBV bebas dalam darah atau cell free EBV. Sumber dari EBV bebas dalam darah pasien KNF berasal dari virion EBV yang keluar dari sel-sel tumor yang mengalami lisis atau DNA yang terintegrasi dengan DNA genom di dalam limfosit (Haryanto \& Sofia, 2012).

Beberapa penelitian telah dilakukan untuk mendiagnosis KNF dengan metode berbasis PCR.Deteksi genom EBV dalam darah pasien KNF telah terbukti dapat digunakan dalam penapisan (screening) penderita, pemantauan penyakit dan penentuan tingkat prognosis penyakit. Penelitian yang dilakukan Hsiao et al. (2002) menemukan bahwa penambahan siklus PCR akan meningkatkan kemampuan deteksi genom EBV dalam darah pasien KNF. Hasil PCR dengan kondisi 35 siklus dapat mendeteksi 38,9\% dan kondisi 50 siklus dapat meningkat positivitas deteksi genom EBV menjadi $75 \%$. Mutirangura et al. (1998) menyatakan bahwa hasil positif dalam deteksi genom EBV pada penderita KNF dengan menggunakan metode PCR konvensional 35 siklus di Thailand adalah 13 dari 42 pasien (31\%). Shotelersuk et al. (2000) mendapatkan hasil positif dalam deteksi genom EBV pada penderita KNF sebanyak 98 dari 167 penderita (60\%) menggunakan metode nested-PCR di Thailand. Pada penelitian di Malaysia menunjukkan positivitas deteksi gen LMP1 yang terdelesi $30 \mathrm{bp}$ pada penderita KNF tipe WHO III adalah $56 \%$ (Hsu et al., 2009). Hasil penelitian ini dengan 
metoda PCR dua tahap menunjukkan positivitas gen BRLF1 sebesar $72,73 \%$ mempunyai sensitivitas yang cukup tinggi, sehingga berpotensi untuk digunakan sebagai petanda molekul dalam diagnosis KNF.

Pada 6 dari 22 sampel penelitian (27,27\%) setelah diamplifikasi menggunakan metode PCR konvensional dua tahap tidak terdeteksi gen litik BRLF1 yang dapat disebabkan oleh beberapa hal, yaitu:

1. Konsentrasi dan kemurnian DNA EBV rendah. Menurut Syafaruddin\& Tri (2011), kualitas DNA yang baik dan tidak terkontaminasi akan meghasilkan pola pita yang jelas ketika digunakan sebagai template PCR.

2. Adanya variasi genetik EBV. Mutasi basa nukleotida pada ujung 3' di lokasi penempelan primer dapat mengakibatkan gen BRLF1 tidak terdeteksi karena amplifikasi fragmen gen ini tidak dapat berlangsung akibat gangguan pada tahap penempelan primer. Karakteristik mutasi yang terjadi di ujung 3' dari lokasi penempelan primer telah digunakan sebagai basis metode PCR SequenceSpecific Primers (SSP) untuk menganalisis mutasi basa nuklotida tunggal. PCR-SSP adalah suatu metode genotipik DNA berdasarkan penggunaan primer dengan urutan spesifik, di mana ketidaksesuaian satu basa pada ujung 3' akan menghambat penempelan primer pada template yang tidak spesifik, sehingga hanya yang benarbenar spesifik saja yang akan diamplifikasi (Welsh \& Bunce, 1999).

3. Jumlah EBV dalam darah yang rendah. Menurut Wong et al. (2004), jumlah CellFree DNA EBV di dalam sirkulasi pasien KNF sekitar $28,79 \mathrm{ng} / \mathrm{ml}$, sehingga jumlah genom EBV yang terlalu sedikit dalam darah pasien dapat menyebabkan tidak terdeteksinya gen BRLF1.

4. Tipe KNF. Tipe KNF dapat menyebabkan tidak terdeteksinya genom EBV dalam darah pasien karena hanya KNF tipe WHO3 yang konsisten infeksi EBV.Sampel dengan nomor 20 berdasarkan hasil pemeriksaan patologi anatomi merupakan karsinoma sel squamosa invasif tidak berkeratin berdiferensiasi moderat atau KNF WHO-2.KNF TIPE WHO-3 dan

\section{Daftar Referensi}

Ariwibowo, H., 2013. Faktor Risiko Karsinoma Nasofaring. CDK-204, 40(5), pp. 348-251.

Barnes, L., Eveson J. W., Reichart P. \& Sidransky D., 2005. World Health Organization Classification of Tumours.Pathology and sebagian KNF WHO-2 berhubungan erat dengan peningkatan titer $\mathrm{EBV}$, sedangkan $\mathrm{KNF}$ WHO-1 tidak memperlihatkan karakteristik tersebut (Neel et al., 1984). Ariwibowo (2013) menambahkan bahwa konsistensi infeksi EBV dengan KNF WHO-2 kurang dari 50\%, sedangkan konsistensi infeksi EBV dengan KNF WHO3 berkisar $90 \%$.

5. Tidak adanya EBV pada pasien KNF. EBV memiliki hubungan kuat dan konsisten terhadap KNF. Namun, selain EBV terdapat faktor-faktor risiko lain yang menyebabkan KNF. Ariwibowo (2013) menyatakan bahwa selain EBV, riwayat keluarga dengan $\mathrm{KNF}$ memiliki hubungan kuat dan konsisten terhadap KNF.Konsumsi ikan asin secara rutin dan genotip HLA kelas I memiliki hubungan sedang hingga kuat dan konsisten terhadap KNF. Faktor risiko yang tidak selalu konsisten yaitu kurang makan sayur dan buah, merokok, kondisi traktus pernafasan kronik, dan makanan berpengawet lain yang berhubungan lemah hingga sedang dengan KNF. Faktor risiko yang tidak konsisten meningkatkan KNF yaitu obat herbal, debu, dan formaldehid dengan kekuatan hubungan lemah hingga sedang.

\section{Simpulan}

Berdasarkan hasil dan pembahasan penelitian, maka diperoleh kesimpulan bahwa gen BRLF1 sebagai petanda molekuler siklus litik Epstein-Barr virus pada penderita karsinoma nasofaring dapat diidentifikasi dengan teknik PCR konvensional dua tahap yang akan menghasilkan pita DNA berukuran $157 \mathrm{bp}$. Sensitivitas metode PCR konvensional dalam mendeteksi gen BRLF1 yang didapatkan dalam penelitian ini adalah $72,27 \%$.

\section{Ucapan Terima Kasih}

Terima kasih kepada dr Anton Budhi Darmawan, MSi.Kes, SpTHT selaku Kepala Poli THT, RSUD Prof. Margono Soekarjo, Purwokerto, atas ijin pengambilan sampel penelitian dan data rekam medis pasien KNF.

Genetics of Head and Neck Tumours. Lyon: IARC Press.

Bhende, P. M., Seaman W. T., Delecluse H. J. \& Kenney, S. C., 2004. The EBV Switch Protein Z, Preferentially Binds and Activates the Methylated Viral Genom. Nat Genet, 36(10), pp. 1999-2004. 
Cacais, A. O. G., 2008. Immunological Consequences of Epstein-Barr Virus Replication. Dissertation. Stockholm, Sweden: Department of Microbiology, Tumor and Cell Biology, Karolinska Institutet.

Chang, E. T. \& Adami H. O., 2006. The Enigmatic Epidemiology of Nasoparhyngeal Carcinoma. Cancer Epidemiol Biomarkers Prev, 15, pp. 1765-1777.

Chang, Y., Chang S. S., Lee H. H., Doong S. L., Takada K. \& Tsai C. H., 2004. Inhibition of the Epstein-Barr Virus Lytic Cycle by Ztatargeted RNA Interference. J Gen Virol, 85, pp. 1371-1379.

Cho, W. C., 2007. Nasopharyngeal Carcinoma: Molecular Discovery and Progress. Mol Cancer, 6(1), pp. 43-56.

Cottrill C. P. \& Nutting C. M., 2003.Tumors at the Nasopharynx. London: Martin Dunitz.

Fachiroh, J., Schouten T. \& Hariwiyanto B., 2004. Molecular Diversity of Epstein-Barr Virus $\lg G$ and $\lg A$ Antibody Responses in Nasopharyngeal Carcinoma: A Comparison of Indonesian, Chinese and Europen Subject. The $\mathrm{J}$ of Infectious Diseases, 190(1), pp. 53-62.

Fles, R., Wilderman M. A., Sulistiono B., Haryana S. M. \& Tan I. B., 2010.Knowledge of General Practioners about Nasopharyngeal Cancer at Puskesmas in Yogyakarta, Indonesia. BMC Medical Education, 10(81), pp. 1-6.

Gautama, E. E., Hariwiyanto, B., Rianto, B. U. D. \& Christanto, A., 2001. Gangguan Indra Pengecap dan Penghidu Pasca-terapi Karsinoma Nasofaring. CDK 187, 38(6), pp. 437-437.

Haryanto, A., \& Sofia M., 2012. Isolasi dan Amplifikasi Gen Penyandi Domain CTerminus Latent Membrane Protein (LMP-I) Epstein-barr Virus (EBV) dari Penderita Karsinoma Nasofaring (KNF). J Sain Vet, 18(2), pp. 1-7.

Hsiao, J. R., Yin T. J. \& Sen T. T., 2002. Detection of Cell Free Epstein-Barr Virus DNA in Sera from Patients with Nasopharyngeal Carcinoma. Cancer, 94(3), pp. 723-729.

Hsu W. L., Chen J. Y.\& Chien Y. C., 2009. Independent Effect of EBV and Cigarette Smoking on Nasopharyngeal Carcinoma: a 20-Year Follow-Up Study on 9,622 Males without Family History in Taiwan. Cancer Epidemiol Biomarkers Prev, 18(1), pp. 1218-1226.
Jemal, A., Bray F., Center C. C., Ferlay J., Ward E.\& Forman D., 2011. Global Cancer Statistics. Ca Cancer J Clin, 61, pp. 69-90.

Kenway N., Leung S. F., Johson P.J. \& Woo J., 2004. Nutritional Consequences of Radiotherapy in Nasopharynx Cancer Patients.J of Nutrition and Cancer, 2(1), pp. 156-161.

Lo Y. M. D., Chan L. Y. S., Lo C. K. W., Leung S. F., Zhang J. \& Chan A. T. C., 1999. Quantitative Analysis of Cell-Free EpsteinBarr Virus DNA in Plasma Patients with Nasopharyngeal Carcinoma. Cancer Res, 59(1), pp. 1188-1191.

Lutan R. \& Zachreini I., 1999. Immunohistochemical Corelation between Nasopharyngeal Carcinoma and Epstein Barr Virus. Asean OtorhinolaryngologyHead and Neck Surgery J, 3(3): pp. 257259.

Munir, D., Ramsi L., Mangain H., \& Fauziah H., 2007.Ekspresi Protein p53 Mutan pada Karsinoma Nasofaring. MKN, 40(3), pp. 163-172.

Mutirangura A., Pornthanakasem W., Theamboonlers A., Sriuranpong V., Lertsanguansinchi P. \& Yenrudi S., 1998. Epstein-Barr Virus DNA in Serum of Patients with Nasopharyngeal Carcinoma. Clin Cancer Res, 4(1), pp. 665-669.

Neel, H. B., Pearson G. R. \& Taylor W. F., 1984. Antibodies to Epstein-Barr Virus in Patient with Nasopharyngeal Carcinoma and Comparison Groups. Ann Otol Rhinol Laryngol, 93(1), pp.447-482.

Roezin, A., 1999. Berbagai Faktor Penyebab dan Predisposisi Karsinoma Nasofaring. Maj Kedokt Indon, 49(3), pp. 85-88.

Sambrook, J. \& Russel D.W., 1989. Molecular Cloning: A Laboratory Manual. New York: Cold-Spring Harbor Laboratory Press.

Savitri, E \& Sofia M. H., 2012.Profil Viral Load Ebstein-Barr Virus dan Titer Antibodi Ig A (VCA-P18+ EBNA-1) pada Karsinoma Nasofaring di Makassar dan Yogyakarta. J Indon Med Assoc, 62(5), pp. 174-177.

Shotelersuk K., Khorprasert C., Sakdikul S., Pornthanakasem W., Voravud N. \& Mutirangura A., 2000. Epstein-Barr virus DNA in Serum/Plasma as a Tumor Marker for Nasopharyngeal Carcinoma. Clin Cancer Res, 6(1), pp. 1046-1051.

Soepardi, E. A., Iskandar N., Bashiruddin J., Restuti R. D., 2007. Buku Ajar IImu Kesehatan : Telinga Hidung Tenggorok 
Kepala dan Leher. Edisi ke 6. Jakarta: Balai Penerbit FKUI.

Steven, S. J. C., Verkuijlen S. A. W. M., Hariwiyanto B., Harijadi, Paramita D. K., Fachiroh J., Marlinda A., Tan I. B., Haryana S. M. \& Middeldorp J. M., 2006. Noninvasive Diganosis of Nasopharyngeal Carcinoma: Nasopharyngeal Brushing Reveal High Epstein-Barr Virus (EBV) DNA Load and Carcinoma-Specific Viral BARF1 mRNA. Int J Cancer, 119, pp. 608-614.

Stevens, C. R. \& Rassekh C., 1998. Nasopharyngeal Carcinoma. New York: Department of Otolaryngology.

Surzycki, S., 2000.Basic Techniques in Molecular Biology. Berlin: Springer-Verlag.

Syafaruddin \& Tri J. S., 2011.Optimasi Teknik Isolasi dan Purifikasi DNA yang Efisien dan Efektif pada Kemiri Sunan (Reutalis trisperma (Blanco) Airy Shaw). J Littri, 17(1), pp. 11-17.

Tselis, A. C. \& Hal B. Jenson, 2006.Epstein-Barr Virus. New York: Taylor \& Francis.
Wahyono, D.J., Musa, Z., Lisnawati, Suryandar, D.A., Hermani, B., Soeharso. P. Hostpathogen study : The relative expression of mRNA BRLF1 Epstein-Barr virus : a potensial use for biomarker of tumor progresivity \& polymorphisms of TCRBC andTCRGC2 penjamu genes related to genetic susceptibility on nasopharyngeal carcinoma. BMC Proceeding 2016: $7^{\text {th }}$ Biannual International Symposium on Nasopharyngeal Carcinoma 2015, Yogyakarta, Indonesia.

Welsh, K. I. and Bunce, M., 1999. Molecular TTyping for the MHC with PCR-SSP. Immunogenetics, 1(1), pp. 156-176

Wong, Thian-Sze, Dora Lai-Wan Kwong, Jonathan Shun-Tong Sham, William Ignace Wei, Yok-Lam Kwong, \& Anthony Po-Wing Yuen, 2004. Quantitative Plasma Hypermethylated DNA Markers of Undifferentiated Nasopharyngeal Carcinoma. Clinical Cancer Res, 10(1), pp. 2401-2406. 